Citation: Sosnowski, W. P., \&, Satoła-Staśkowiak, J. (2019). A contrastive analysis of feminitives in Bulgarian, Polish and Russian. Cognitive Studies / Etudes cognitives, 2019(19). https://doi.org/10.11649/cs.1922

\author{
${ }^{1}$ Institute of Slavic Studies, Polish Academy of Sciences, Warsaw, Poland \\ ${ }^{2}$ Academy of Humanities \& Economics in Lodz, Poland \\ $A_{\text {wojciech.sosnowski@ispan.waw.pl }}$ \\ https://orcid.org/0000-0001-9299-4505 \\ $B$ jstaskowiak@ahe.lodz.pl \\ https://orcid.org/0000-0002-8821-2379
}

WOJCIECH PAWEŁ SOSNOWSKI ${ }^{1, A}$, JOANNA SATOŁA-STAŚKOWIAK ${ }^{2, B}$

\title{
A CONTRASTIVE ANALYSIS OF FEMINITIVES IN BULGARIAN, POLISH AND RUSSIAN
}

\begin{abstract}
The subject of this article is the contemporary usage of feminitives (specifically the names of occupations and functions), which traditionally are most often derived from masculine names. The article presents a contrastive analysis of feminitive usage in three Slavic languages: Bulgarian, Polish and Russian. The article examines the problem of linguistic asymmetry in the creation of feminine names in the three languages and presents the views of renowned linguists on the issue. Keywords: feminitives; Bulgarian language; Polish language; Russian language; language asymmetry; contrastive analysis; androcentrism
\end{abstract}

\section{Introduction}

1.1 The subject of this article is the contemporary usage of feminitives (in particular the names of occupations and functions), which traditionally are most often derived from masculine names, and a contrastive analysis of said usage in three Slavic languages: Bulgarian, Polish and Russian. The sources of the material presented are the Internet (Internet forums, blogs and social networking sites) and the press (including the so-called women's press) in both paper and electronic versions.

The aim of the article is to analyse the feminitive linguistic phenomena present in the language communication of three Slavic countries: Bulgaria, Poland and Russia. The contrastive analysis of the Slavic languages used in these countries has become very important as they represent all three Slavic language groups, namely the southern (Bulgarian), western (Polish) and eastern (Russian) groups. The aim is to trace the current state of the use of feminine names of professions and to examine the similarities and differences observed during this analysis.

The term feminitives (Bg. феминитив, Rus. феменитив, Pol. feminatyw) is to be understood as "nouns that refer to feminine names of professions and functions, most frequently derived from 
masculine names with the help of a suffix of the feminativum category or directly from verbs with a complex suffix of a category of agents" (Laziński, 2006, p. 246). It can be argued that regular derivation of feminitives in a given language creates a gender-linguistic balance in said language.

1.2 The continued use of masculine forms in cases referring to mixed-group nomenclature is a characteristic feature of all Slavic languages, even when women largely outnumber male members of the group. Using masculine profession names where there are feminine equivalents is more typical of some languages than of others. In modern Slavic languages, for example, this happens in Bulgarian, Polish and Russian, but less often in Slovak or Czech, in which the ease with which feminine forms can be created from masculine forms is well-known. Many linguists have written on this subject and other important elements of women's and men's linguistic reality. With regards to Bulgarian, researchers include, among others, Borislav Georgiev (Georgiev, 2012), Vladko Murdarov (Murdarov, 2011, 2012), Vanina Sumrova (Sumrova, 2001-2002), Ljubomir Andreychin (Andrě̌chin, 1969, 1973, 1974), and Joanna Satoła-Staśkowiak (Satoła-Staśkowiak, 2018). In the Polish language, notable research includes Jerzy Bralczyk (Bralczyk, 2014), Kwiryna Handke (Handke, 2008), Małgorzata Karwatowska and Jolanta Szpyra-Kozłowska (Karwatowska \& SzpyraKozłowska, 2010), Jan Miodek (Miodek, 2010), and Marek Łaziński (Łaziński, 2006). In the field of the Russian language, research has been conducted by Veronika Berkutova (Berkutova, 2017), Anna Vasilieva (Vasil'eva, 2016), Julia Shemchuk, Aleksandra Andreeva A. (Shemchuk \& Andreeva, 2013), and, based on comparative material of Polish and Russian languages with reference to Czech, Katarzyna Dembska (Dembska, 2012) and many others. ${ }^{1}$ In this research work, linguistic trends, environmental divisions, stylistic differences, and sometimes the absurdities of the languages were emphasized.

1.3 Feminist linguistics emerged in the second half of the 20th century, initially in countries such as Sweden, Germany and the USA, and then spread throughout Europe and other parts of the world. Its primary purpose was to deny and stop the spread of androcentrism, a phenomenon wellknown in the majority of cultures, due to the historical prevalence of patriarchal social systems. Nowadays (i.e. in the first half of the 21st century) heterogeneous activity in the creation and use of feminitives has been observed in various social groups and in different languages. In societies with a compelling need to change their existing linguistic structures, change can be observed among language users in the perception of reality and in the understanding of the role of women in modern society. The creation and use of feminitives or, conversely, their avoidance, clearly characterise current social relations and relations between the sexes - their way of reasoning, communication, and attributing characteristics to each other. Language is very closely intertwined to thought. Therefore, in a situation of changing attitudes towards new language forms, one may advance the thesis that the creation, codification, description and active use of feminine profession names in particular languages may lead, in the not too distant future, to a departure from the androcentrism of culture, which so far has been so strongly expressed on a formal level by language.

\section{Linguistic Asymmetry}

2.1 Even a preliminary juxtaposition of the studied lexis lends support to the thesis that the feminine names of professions in the Bulgarian, Polish and Russian languages are currently not applied equally and symmetrically. A noticeable linguistic asymmetry in the creation of profession names is observable in all three languages, although more clearly in Polish and Russian than in Bulgarian.

\footnotetext{
${ }^{1}$ Feminitives have recently been described in other Slavic languages, e.g. Belarussian, in the book: «Гід па фемінізацыі беларускай мовы», Уладзіслаў Гарбацкі (Harbatski, 2012).
} 
2.2 Since the objects under analysis are Slavic languages, it should be noted that the richness of the Slavic language family in terms of suffixes considerably exceeds the possibilities of deriving feminine forms in other languages (cf. the relatively few English, German, French suffixes, etc.). For this research it was necessary to verify what linguistic resources Slavic languages use in order to create the feminine names of professions and functions. The initial observations confirmed the hypothesis that language users willingly use historically established suffixes. This means that instead of creating new word formation models, new lexemes are created with existing suffixes. It seems reasonable to say that the task of linguists is to help codify the standards of creating feminitives, as at present users of the three languages tend to create these forms intuitively by themselves. Significant social changes at the end of the 20th and the beginning of the 21st century have resulted in women occupying all available professional roles and it is only natural that language should respond to this phenomenon.

2.3 A very active word formation process in the Bulgarian, Polish and Russian media is currently taking place with regard to feminitives. The recently created lexemes can be considered neologisms. In the work "Словарь гендерных терминов", the term feminist neologism is used with regard to this phenomenon (Denisova, 2002). The appearance of lexemes included in this group is very often considered against the background of the processes that have earlier took place in English (e.g. the departure from words with the particle man in favour of person in a word such as salesperson instead of salesman or police officer instead of policeman). In fact, the struggle against androcentrism in language can be observed in many countries. However, when analysing Slavic languages, a comparison with the relevant structural changes in the English language is of limited use, since English does not have gramatical gender. Grammatical gender goes together with other connotations and intrasystemic possibilities to underline the female sex of a professional (e.g. a combination of masculine nouns with the feminine form of verbs in the past tense: врач сказала, секретарь выступила). Therefore, the Slavic languages should be analyzed without contrasting them with languages of other groups. On the other hand, when it comes to non-linguistic reality, a departure from emphasizing gender at the level of word-formation is clearly noticeable in speech acts in English-speaking countries.

It has become common to believe that the need to reduce or balance the asymmetry regarding the professional nomenclature of women and men has been primarily a concern for the feminist movement. This view, however, oversimplifies the phenomena observed in society, and consequently in language. Some linguists rightly emphasize that the "battle for language" or "formal representation" is not so much about making it more symmetrical with regard to gender as it is about not discriminating on the basis of gender. This is important to many language users (Karwatowska \& Szpyra-Kozłowska, 2010, pp. 11-56). According to some researchers, the use of masculine names of professions (especially in cases where feminine names exist) is a sign of androcentrism (Zhukova, Lebed'ko, Proshina, \& Iuzefovich, 2013).

\section{Contrastive analysis}

\subsection{Bulgarian}

3.1.1 Traditionally, the Bulgarian language creates the names of female professions based on male forms, without any word-formation problems. The direction of creating feminine names (from masculine to feminine) is characteristic of all the languages compared in this article. The formative $-k a$ is used to create the largest group of feminitives in Bulgarian (министорка, прокурорка, сгдийка, деканка, войничка, лейтенантка, офицерка). Other formatives include: -ша (президентша, премиерша, министврпредседателша, депутатша, дипломатша), -джийка (атакаджийка, хайлайфаджийка), -манк(а) (меломанка, ароматоманка, блогоманка, графитоманка) and -холичк(а) (работохоличка, книгохоличка, кафехоличка) (Sumrova, 2018). 
It is undisputable that in Bulgarian there is an imbalance between masculine and feminine forms in names for professions (Babov, 1964). However, the phenomenon of using the masculine names of professions for both men and women in modern Bulgarian, a practice which started after the end of the Second World War, conflicts with the nature of the language and has been criticized by some linguists (Bokale, 2009; Murdarov, 2011; Vlakhova, 2001). Bulgarian researchers attribute the overall direction of contemporary linguistic changes to a strong Russian influence, which has given rise to common Bulgarian forms such as жена-космонавт, жена-герой (cf. the contemporarily derived and actively used Russian model: женщина президент, женщина политик; женщина епискоn) (Andreĭchin, 1961, 1969, 1974; Babov, 1964, p. 213). However, they also argue that language trends and the need to distinguish between the formal and colloquial registers (with the former's smaller variety of forms) play a significant role in the aforementioned masculinization.

In colloquial spoken Bulgarian, feminitives such as министорка, професорка and космонавтка unlike жена министор, жена професор, жена космонавт do not carry any negative connotation (Babov, 1964; Vlakhova, 2001). There is a vast difference between the formal and colloquial registers in Bulgarian. In the former, the same feminine forms министорка, президентка or посланичка have a depreciative meaning. (Vlakhova, 2001)

3.1.2 Traditionally, the majority of generic names for professions are masculine nouns (e.g., npoфесор, прокурор, адвокат, министгр, нотариус, съдия еtс.). To refer to a woman's professional occupation, the female form of the profession is created from the masculine noun (without the phonetic barriers that can be seen in some Polish feminitives such as adiunktka). However, there is a small group of occupations for which the opposite is true. These are professions historically associated with, and dominated by, women and which are generally considered as 'unmanly', such as болногледачка, бродировачка, детегледачка, домашна помощничка оr домашна работничка, камериерка, козметичка, маникюристка.

Last year (2018) the Institute of Bulgarian Language of the Bulgarian Academy of Sciences in Sofia published the first linguistic study by Vanina Sumrova, covering more than 1,400 new (created in the last 25 years) feminitives in Bulgarian. A large part of the material collected in the study comes from the dictionary Rechnik na novite dumi v balgarskia ezik (ot kraya na $X X$ i parvoto desetiletie na XXI v.) (Речник на новите думи в българския език (от края на XX и първото десетилетие на XXI в.)) by E. Pernishka, D. Blagoeva and S. Kolkovska (Pernishka, Blagoeva, \& Kolkovska, 2010; pp. 515), which is the richest existing dictionary of Bulgarian neologisms, as well as a dictionary entitled Rechnik na novite dumi $i$ znachenia $v$ balgarskia ezik (Речник на новите думи и значения в българския език) by the same authors (Pernishka, Blagoeva, \& Kolkovska, 2003; pp. 309). The author discusses feminitives in different contexts (semantic, stylistic, word formation, cultural-linguistic). She makes a successful attempt to explain the causes behind the start of the masculinization process and its continued duration. She also describes the intriguing phenomenon of women's self-nomination, as well as the issue of language discomfort - the inconvenience of masculinization or the difficulties and language errors which it causes: Министърът на земеделието и горите Десислава Танева и заместниците му (примерът е от архива на Службата за езикови справки в ИБЕ при БАН); Съдии от СГС поискаха оставката на председателя Владимира Янева и заместниците му; Моят психотерапевт казва, че [.. . ] и затова спрях да я посещавам (Sumrova, 2018, p. 104). Sumrova accurately presents the positions of numerous Bulgarian linguists. The author discusses the "media revolution" (Znepolski, 1997) - and the invasion of colloquialisms that has played a significant role in the process of renewing and/or building a new Bulgarian vocabulary. She also agrees with V. Tabakova (Tabakova, 1995, p. 81), stating that in Europe, as in Bulgaria, "women make up the majority of the population" (p. 9), and therefore it is important to follow current linguistic processes and to reflect on their actions with specific examples in Bulgarian. 
3.1.3 Despite the existence of a codified system for creating Bulgarian feminitives, language users deliberately reject the use of feminine counterparts of the names of professions (built with the suffix -ка, such as професорка, прокурорка, адвокатка, министгрка, свдийка). When referring to a profession in general, rather than a specific individual belonging to that profession, the use of a masculine noun is generally perceived as neutral (i.e. referring to both men and women). In formal speech, the masculine form is also used to denote the position or professional title of a female individual, e.g. съдия Петрова, адвокат Николова, нотариус Емилова, дознател Бойчева, прокурор Стаменова, доктор Абаджиева. In such cases, the female gender can still be observed in other parts of speech referring to the post-holder (e.g. the masculine form of a profession's name combined with the feminine form of a verb or participle). The following sentence provides a good illustration: За министгр на околната среда беше избрана Нона Караджова (cf. Murdarov, 2011, p. 1). However, this practice lacks consistency. When reporting on the same visit by a female minister, for example, different newspapers used different approaches: Министоргт е бил посрещнат на аерогарата - Министоргт е била посрещната на aерогарата.

3.1.4 Similarly to Polish and Russian, the choice of noun form can be influenced by the negative connotations of some of the forms. This is most often associated with a decrease in the prestige of a person practising a given profession. Common lexemes such as лекарка, учителка, твкачка are semantically neutral. These tend to be occupations that have long been practiced, or even dominated, by women (typically caring professions, e.g., медицинска сестра, директорка (на ясла, детска градина, училище)). However, for professions which have only recently become more inclusive of women, their feminitive forms (e.g. президентка, министгр-председателка, премиерка, главна редакторка, кметка, ректорка, заместник-ректорка) do not possess the same neutrality. This leads to the current asymmetry of the Bulgarian language and its failure to fully adjust to contemporary realities (Georgiev, 2012).

The latest data observed in the Bulgarian language corpus shows that the number of feminitives commonly used by language users is slowly increasing. This may indicate that the fashion for masculine forms is beginning to change, so contemporary tendencies in Bulgarian should be closely followed.

\subsection{Polish}

3.2.1 Some professions in Polish do not have an equivalent word formation counterpart in the feminine form - e.g. chirurg, górnik, pilot, prezydent. Attempts to create feminine forms from words such as a psycholog or minister arouse heated discussions and resistance, both among linguists and in society at large (Handke, 2008). In Polish, a great deal of controversy surrounds the issue of feminine endings. The former Polish People's Republic is often blamed for this situation, and we are reminded that feminine forms were widely used in the interwar period. One of the most vivid examples is the form doktorka as a term for a woman with a doctorate degree (Dryjańska, 2016).

3.2.2 As in the case of names, the vast majority of the names of professions in Polish, which have masculine and feminine equivalents, are created from the former (e.g. lekarz and lekarka, nauczyciel and nauczycielka, urzędnik and urzędniczka, prawnik and prawniczka). This practice has its roots in history. Some of these forms still carry a pejorative meaning for a significant proportion of language users (prezes - prezeska, doktor - doktorka, profesor - profesorka, dyrektor - dyrektorka), or they are not equivalent (sekretarz-sekretarka, połoznik-połozna). If a profession does not have a masculine form, it is usually not very prestigious and is assigned to women (because most men consider it to be unmanly), e.g. niania or przedszkolanka. Moreover, if there is a man who wants to work as a niania or przedszkolanka (nanny or nursery school teacher), he is not 
taken seriously. In the case of these professions, the situation is analogous to that which can be observed in Bulgarian.

Feminine names with the suffix $-k a$ (derived from the names of prestigious male professions) have been recognized in recent decades as unofficial and disrespectful. Hence, in place of dyrektorka or profesorka, terms expressing respect appeared: pani dyrektor, pani professor. This approach became common after the Second World War. Previously, most of the names of professions had a form in both genders. In an 18th century dictionary there were even terms such as administratorka, dozorczyna, karczmarka, klucznica, kuchmistrzyni, piekarka, rzadczyna, szafarka, urzędniczka, węglarka, wierszopisyni, wielkorzadczyni. At the beginning of the 20th century, profesorka, postanka or dyrektorka did not yet have any negative connotation. Currently, if these terms are used at all, they are not used in the ordinary meaning of the word and are not equivalent to their masculine forms, e.g. professor (at a university) - profesorka (in a secondary school), dyrektor (of a factory) - dyrektorka (of a kindergarten or school), połoznik (doctor) - położna (a nurse specialising in midwifery).

3.2.3 In order to create feminitives in Polish, the following formatives are used: - $k a$ (doktor - doktorka, profesor - profesorka), -i(y)ni (zarzadca - zarzadczyni, językoznawca - językoznawczyni), -a (minister - ministra), -owa (ksiegowy - ksiegowa), -i(y)na (wojewoda - wojewodzina), -icha, -essa/-esa (hostessa), -arka (piekarz - piekarka), -anka (przedszkolanka), -ówka, although the feminine noun forms of names are generally made from masculine forms with the suffix $-k a$ (e.g. nauczyciel - nauczycielka, socjolog - socjolożka, psycholog - psycholozka) or -ini/-yni (władca - władczyni). The ending - $a$ is used with names that are adjectives, e.g. przewodniczacy - przewodniczaca, służacy - służaca, habilitowany - habilitowana (Łaziński, 2006, pp. 254-258).

3.2.4 The reluctance to use feminine forms in the Polish language to describe women's professions can be explained by the frequent semantic shifts in the language, a consequence of which is that the masculine form sometimes signifies something other than its formal feminine counterpart, e.g. tirowiec (lorry driver) - tirówka (prostitute), maszynista (train driver) - maszynistka (typist, a woman typing texts on a trypewriter), kominiarz (chimney sweep) - kominiarka (balaclava, a type of hat), ciężarowiec (weight lifter) - ciężarówka (lorry), dziekan (dean) - dziekanka (dean's leave), dyplomata (diplomat) - dyplomatka (a type of briefcase), magister (Master's degree; a person with a Master's degree) - magisterka (Master's thesis), marynarz (sailor) - marynarka (jacket), pilot (pilot) - pilotka (aviator hat), reżyser (film or theatre director) - reżyserka (film director's room, control room). The semantic difference between a feminine and masculine form describing a particular profession determines the choice of the masculine form as "neutral" and "more appropriate" for the description. There are no cases in the Polish language of a feminine form used to name a man's profession being considered "neutral".

3.2.5 A strong opinion on the use of feminine derivatives ending in $-k a$ has been expressed by Maciej Malinowski, who claims that for years women preferred, and were proud of, the possibility to use the masculine names of professions, because of the perceived inferiority or frivolity conveyed by the suffix $-k a$.

"Nobody dared to address a female university professor (pani professor) with words pani profesorko, say pani doktorko to a female doctor (pani doctor) in a hospital, or say pani mecenasko to their female lawyer (pani mecenas). Obviously, sometimes rather inelegant words such as kierowniczka, matematyczka, fizyczka, chemiczka were heard, but only in private, behind-the-scenes conversations" (Malinowski, 2006, p. 1). Maciej Malinowski also draws our attention to phonetic considerations, which for certain professions are the reason why women choose the masculine form, instead of the difficult to pronounce forms adiunktka, architektka, subiektka, pedriatrka. The author invokes hypothetical examples (with the -ini suffix), such as chirurgini, dramaturgini, kierowczyni, which, in his opinion, additionally emphasise the ridiculousness of such obtained forms. 
Despite these views, numerous examples of using feminitive forms, such as socjolozka, filolożka, psycholożka, pedagożka, politolożka, antropolożka, polityczka, marszałkini, weterynarka, ${ }^{2}$ are easily found in the press and on internet forums. This reflects broader cultural, linguistic and societal shifts. However, the practice remains somewhat controversial, having its supporters and distractors among both sexes.

3.2.6 The emotional confusion and sensitivity surrounding this issue are illustrated by the following description provided by Jan Miodek, Piotr Komander, Mirosław Mycawka and Jerzy Bralczyk: "A matematyczka who is talking to me wants to be a nauczyciel matematyki (God forbid nauczycielka!), her female colleague introduces herself as a biolozka. A woman complains about psycholozka and socjolozka, but she has no objection to profesorka and polonistka" (Miodek, 2010). Miodek recalls, as an illustration of the phenomenon, something that he read in the obituary of an eminent female scholar, "Wybitna socjolog, dtugoletni pracownik, przewodniczaca Rady Naukowej, kierownik Zakładu, oddana pracy", and lists the feminine forms from one edition of "Gazeta Wyborcza": "psycholog seksuolog kliniczny, wiceprezes, publicystka (dwa razy), socjolożka, autorka, adiunkt, członkini, krytyczka literacka, filozof, przewodniczaca Rady, przewodniczaca komisji, była komisarz, była minister" (Miodek, 2010), in which a mix of masculine and feminine forms is used to refer to the same person.

Piotr Komander, in the text "Żeńskie nazwy zawodów, czyli poślica i profesora" (Feminine names of professions, or poślica and profesora), who views some linguistic equal rights techniques as ironic, writes: "A good example of an unfortunate name change is postanka who was at first called posetka. In the meantime, Professor Bralczyk points out that both forms are wrong, since, following the same pattern as orlica or diablica, the correct form should be poślica. However, forms ending in - $a$ do not always work. The brave women authors of the proposed changes seem not to notice that their ideas make perfect fodder for irony and jokes. Premiera sounds like a film or theatre premiere (Pol. premiera), ministra sounds like the possessive form of the word minister (czyja? Ministra - whose? the minister's). Profesora makes one think of a person who is large boned, rather than a title. In his opinion: "Adding the $-k a$ suffix does not do the trick either. It often sounds insufficiently serious or infantile (a feature of the diminutive - gwiazdka, kurka) and even offensive. It is risky to call a university professor pani profesorko. To my mind, words like mecenaska, ministerka, doktorka, filozofka do not sound right either. Is oficerka a female officer or a leather boot? Are marynarka, pilotka, literatka, tokarka women or objects? Similarly, what about drukarka and tapicerka? Reżyserka is a room in a radio or television studio. There is also a phonetic problem: the pronunciation of forms such as adiunktka, pedriatrka, architektka is not easy at all." (Komander, 2017)

Mirosława Mycawka points to certain rules that have become outdated in recent years. These include the rule related to the use of the $-k a$ suffix. According to the author, when using the suffix $-k a$, "we cannot create a feminine form from a masculine noun that ends in a consonant cluster (e.g. architect). This barrier does not seem to exist anymore, as this form is recorded in the "Dictionary of contemporary Polish language" and it is more and more often used" (Mycawka, 2001, p. 18).

Jan Miodek writes with sarcasm about the confusion he encountered in the following excerpts: "wybitna socjolog, psycholog seksuolog kliniczny next to socjolozka, pracownik and kierownik next to członkini and krytyczka literacka, devoted publicystka, przewodniczaca, but wiceprezes, komisarz, minister." He later refers to examples of parallel formal usages of terms such as redaktorka naczelna, redaktor naczelna or redaktor naczelny with reference to female chief editors and główna ksiegowa and główny ksiegowy with reference to female accountants. (Miodek, 2010). Miodek points out that similar problems do not exist in Czech and Slovak which have a well-established tradition of using suffixes to create feminine forms (rektorka, dekanka, profesorka, docentka, doktorka, prezeska) or

\footnotetext{
2"Dorota Sumińska - weterynarka z miłości do zwierząt". These forms have as many supporters as opponents (Kozak, 2012).
} 
in German, in which the difference between grammatical genders is less typologically pronounced than in Slavic languages (the German suffix -in, corresponding to the Polish suffix - $k a$, is readily used in lexemes such as Kanzlerin, Ministerin, Rektorin, Dekanin, Professorin) (Miodek, 2010).

\subsection{Russian}

3.3.1 The history of the literary Russian language shows that feminitives have always been used. Forms such as княгиня, государыня, боярыня, сударыня, ключница, иарица, and героиня have entered the language for good. There are also independent names for female performers of various activities such as банщица, ковровщица, веночница, and прядильница. Russian also has feminine forms of professions that have never been given a masculine form, such as noвиmyxa. Thus, contemporary Russian has inherited a whole group of professional names or titles which have been treated as norms and which do not have any negative connotations or stylistic colouring, for example графиня, знахарка and the more modern трактористка, активистка, and стюардесса. It should be stated here that feminine forms were most often derived from masculine forms, but the history of the Russian language also contains reverse cases, e.g. медсестра - медбрат, ведъма ведъмак, доярка - дояр.

3.3.2 In Russian there are ways of forming nouns which define the wives of men who practise particular professions. For high positions, the suffix - ша has been used (e.g. фелъмариальша, адмиральша, губернаторша), and for professions of a lower rank: -ха (е.g. дворничиха, слесариха, мельничиха).

3.3.3 In the 20th century, it became a norm to use feminine names in two cases. Firstly, feminitives were consistently applied to traditional "female" professions, for example доярка and акушерка, and secondly, in those spheres where women had an important place, such as cnopmcменка and студентка. Other forms were also neutral, e.g. писательница, преподавательница, and учительнича. However, the stylistic rules of the Soviet era required the use of masculine nouns in documents, such as преподаватель Иванова, and секретарь Петрова. The use of masculine names of professions was also adopted in all formal situations to give a higher rank to the individual.

Feminine forms were actively used in relation to traditionally "female" professions, such as долp$\kappa a$ and акушерка, and in spheres in which women were prominently represented, e.g. спортсменка and студентка. In other cases, the female sex of a specific professional was conveyed by the use of verbs in the feminine gender in conjunction with the masculine noun designating the profession.

3.3.4 Recent decades have seen the active creation of feminine names of professions. So far, historically inherited word formation resources have been used to this end. The relevant group of

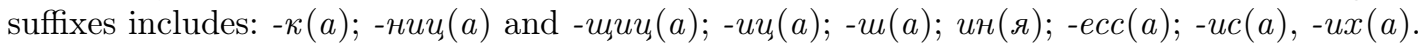

3.3.5 In the collected material the suffix $-\kappa(a)$ is the most widely applied: авторка, комментаторка; директорка; стилистка; режиссёрка; дизайнерка; администраторка; лидерка; фотографка; менеджерка; архитекторка; поэтка; блогерка; координаторка; пресс-секретарка; програмистка; юристка; редакторка; соорганизаторка; журналистка; лаборантка; редакторка; терапевтка; иллюстраторка; аниматорка; геймерка; реперка; персонажка; фрилансерка; профессорка; скульпторка; донорка; товарищка; мемберка; депутатка; психоаналитичка; галеристка and others. There are several reasons behind the frequency of this suffix. Firstly, it is the most neutral in terms of style. The aforementioned lexemes, such as доярка, студентка, and спортсменка, do not carry any negative stylistic colouring. An element of contempt can only be found in a small group of names with this suffix, e.g. училка, about a female teacher, or химичка, about a female chemistry teacher. Secondly, this suffix is widely used in other Slavic 
languages (Bulgarian, Polish, Czech) and is very productive. Thirdly, it has only minimal semantic constraints, although they still do exist, e.g. матроска (a type of garment), машинистка (typist), богатырка (the name of the helmet worn by Red Army soldiers). Some terms created in this way did not last very long, e.g. товарка, derived from товарищ, (although the word moварищка appeared instead). On the other hand, one can observe the activation of older forms created according to this model, e.g. танцорка, актёрка (to replace the existing танцовщица, актриса).

3.3.6 Second in terms of frequency and productivity is the suffix -нии $(a)$ : деятельница; следовательница; руководительница; воспитательница; слушательница; писательница; вдохновительница; создательница; айтишница; предпринимательница; обозревательница; пользовательница etc. The choice of this suffix can be justified by the fact that as early as the twentieth century, the majority of lexemes of this group were considered stylistically neutral (e.g. nuсательнича). Constraints on its use, on the other hand, can be explained by the above-mentioned stylistic opposition, i.e. in official language masculine forms were used, for instance руководитель компании Иванова.

3.3.7 The same can be observed with regard to lexemes ending in -щuи, $(a)$. Some of them have been widely used for a long time (е.g. уборщица, продавщища, сортировщица, and тестировщича), while others are more recent and considerably more colloquial (галерейщица; пиарщица). This group also includes lexemes with the less frequently used suffix -uц, $(a)$. Forms such as u, арица and лётчица are well-established. In addition, the following examples of the recent use of this word formation model, which are currently highly colloquial, have been recorded: доктории, физица; шефица. However, even for professions that have well-established female forms, only the masculine gender is used in formal documentation and job advertisements (уборщик, продавеи).

3.3.8 The productivity of the suffixes $-u a$ and $-x a$ (ie: modern derivatives such as cydruxa, президентша, and богатырша) is far lower. In the case of these suffixes, the reason for their infrequent use lies in their stylistic colouring. In the twentieth century, they expressed a contemptuous attitude (e.g. секретарша), and were used in the colloquial style (маникюрщица, педикюориа). Above all, they had a meaning which has already been mentioned - the wife of a man who practises a particular profession, for instance профессорша, генеральша.

3.3.9 Another productive suffix is $-и н(я)$. The use of this suffix to create female forms of nouns referring to professional occupations started in the twentieth century in the context of narrower professional specializations (филологиня, гинекологиня) and has now been actively adopted by online bloggers to refer to many other occupations (e.g. министриня, фотографиня, хирургиня, психологиня, врачиня).

3.3.10 The international suffix -ecc(a) (cf. French -esse, Italian -essa) remains a productive suffix in Russian: авторесса, министресса, премъер-министресса, адвокатесса, физикесса, деканесса, академесса, политикесса. The less frequent use of this suffix can be explained by cultural considerations. As early as in the 20th century, Russian female poets, following the example of Marina Tsvetayeva, called themselves поэm and rejected the term nоэтесса. The least-frequently used suffix is -иса, for instance директриса, актриса, инспектриса, оr автомотриса. The latest creations in terms of neologisms are feminine adjectival names of professions such as учёная or пожарная.

The future of feminitives in Russian is in doubt. Maksim Krongauz, commenting on the debate on feminitives, says: "we do not want to use words we are not used to and which make us smile. Language use should be natural. I do not think this can be solved. It is too strongly connected to ideological issues. I will, however, express my linguistic view: the point is that language is 
not really going in this direction. As women become increasingly emancipated, as we watch the progress (in particular, the fact that women have all the professions that exist in the world), language reflects this to a greater or lesser extent." (Krongauz, 2018)

\section{Summary}

It is evident that in all three languages discussed in this paper users are increasingly conscious of the existing gender imbalance in language, specifically with regard to professions and occupations. However, a consensus on how gender inclusiveness is best achieved has yet to be worked out. In English, the issue has been resolved in a relatively straightforward manner by shifting towards full gender neutrality, i.e. by avoiding any lexemes that are gendered in one way or other (e.g. "police officer' instead of policeman/policewoman; or 'actor' to refer to both male and female actors instead of referring to the latter as 'actress'). This solution is not readily available for Bulgarian, Polish and Russian speakers because of the existence of grammatical gender. Instead, in all three languages two competing trends are currently observable. One consists of using a single form (typically masculine) to refer to a profession and to the people pursuing it, regardless of their actual gender. This entails avoiding feminitives even then they are well-established and acceptable in formal speech, including in the case of professions in which women traditionally outnumber men. This trend is particularly pronounced in the formal register. The other trend (observed largely in online blogs) is towards always using feminine forms when referring to female professionals, expressly with the purpose of addressing the existing imbalance. This approach often requires the creation of new feminitives, either because the feminine forms do not exist at all, or because the existing ones are negatively coloured.

The languages discussed in this paper share similar morphological and word formation mechanisms which facilitate the creation of feminine equivalents for the names of professions. The quantitative analysis of the state of feminitives has shown that the Russian language, despite the large number of word formation models, remains one of the less consistent language systems, as there are no clearly regulated rules for creating forms for women's professions. It can be observed that language users are increasingly seeking gender inclusiveness with reference to professions through the derivation of feminine forms, including such synonymic word formation sequences as физица, физичка, and физикесса, or pairs such as врачиня - врачица (in order to avoid the use of negatively marked lexemes).

Forms of address, and their implementation in the form of discreet modal operators (Sosnowski, 2016) in the shape of phrases used for a group of people, e.g. Уважсаемые студенты и студентки, remain an unresolved problem. At present, masculine forms dominate when addressing a group. These tendencies and the views of language users stand in opposition to, for example, the Slovak language, cf. the article "Všeobecný mužský rod a maskulinizácia v slovenskom, pol'skom a bulharskom jazykovom prostredî" (Košková \& Satoła-Staśkowiak, 2017).

\section{References}

Andreı̆chin, L. (1961). Na ezikov post. Sofiia: Izd. "Nauka i izkustvo".

Andreĭchin, L. (1969). Obrŭshteniia kŭm sluzhitelki zheni. Bŭlgarski ezik, 19(1).

Andrěchin, L. (1973). Ezikovi trevogi. Sofiia: Izd. "Nauka i izkustvo".

Andreı̆chin, L. (1974). Zashto prodŭlzhavame da nazovavame i tituluvame zhenite s forma za mŭzhki rod? Bŭlgarski ezik, 24(5), 440-441.

Babov, K. (1964). Dumite v ruski ezik "kosmonavt - zhenshchina-kosmonavt" i tekhnite bŭlgarski sŭotvetstviia. Bülgarski ezik, 14(2), 209-214.

Berkutova, V. (2017). Feminitivy v russkom iazyke: Lingvisticheskiǔ aspekt. Retrieved September 21, 2018, from https://docplayer.ru/44005004-Feminitivy-v-russkom-yazyke-lingvisticheskiy-aspek t.html 
Bokale, P. (2009). Profesoa ili profesorka? Rodŭt na imenata, oznachavashti profesii v ukrainskiia i bŭlgarskiia ezik. Ezikov sviat, 7(1), 7-29.

Bralczyk, J. (2014). Premiera, megiera, hetera: Prof. Bralczyk: Już łatwiej być ministrą. Retrieved September 21, 2018, from https://www.tvp.info/16784222/premiera-megiera-hetera-prof-bralczy k-juz-latwiej-byc-ministra

Dembska, K. (2012). Tendencje rozwojowe polskich $i$ rosyjskich nazw zawodowych kobiet na tle języka czeskiego. Toruń: Wydawnictwo Naukowe Uniwersytetu Mikołaja Kopernika.

Denisova, A. A. (2002). Slovar' gendernykh slov. Moskva: Informatsiia XXI vek.

Desperak, I. (2018). Leksykolożka, couchsurferka i korposuka, czyli "Słownik nazw żeńskich polszczyzny". Krytyka Polityczna. Retrieved September 21, 2018, from http://krytykapolityczna.pl/kultura/c zytaj-dalej/leksykolozka-couchsurferka-i-korposuka-czyli-slownik-nazw-zenskich-polsz czyzny/

Dryjańska, A. (2016). Przodkini, reformatorka, twórczyni: Żeńskie nazwy doczekały się własnego słownika. Retrieved September 21, 2018, from http://natemat.pl/171807,przodkini-reformatorka-tworczy ni-zenskie-nazwy-doczekaly-sie-wlasnego-slownika

Dvonč, L., Horák, G., Miko, F., Mistrík, J., Oravec, J., Ružička, J., \& Urbančok, M. (1966). Morfológia slovenského jazyka. Bratislava: Vydavatel'stvo Slovenskej akadémie vied.

Dziurla, R. (2012). Kobieta w języku. Retrieved September 21, 2018, from https://republikakobiet.pl /psychologia/walka_ze_stresem/kobieta-w-jezyku/

Georgiev, B. L. (2012, March 12). Mŭzhkiiat i zhenskiiat rod pri sŭshtestvitelni za profesii i dlŭzhnosti. Retrieved September 21, 2018, from https://bogeo.net/2012/03/12/gender2/

Handke, K. (2008). Językowe wyznaczniki płci. In K. Handke, Socjologia języka. Warszawa: PWN.

Harbatski, U. (2012). Hid pa feminizatsyi belaruskă movy. Vil'nia.

Karwatowska, M., \& Szpyra-Kozłowska, J. (2010). Lingwistyka płci: Ona i on w języku polskim. Lublin: Wydawnictwo Uniwersytetu Marii Curie-Skłodowskiej.

Komander, P. (2017, March 19). Żeńskie nazwy zawodów, czyli poślica i profesora [Blog post]. Retrieved September 21, 2018, from http://secundum.pl/zenskie-nazwy-zawodow-czyli-kierownica-albo-e lektryczka/

Košková, M., \& Satoła-Staśkowiak, J. (2017). Všeobecný mužský rod a maskulinizácia v slovenskom, pol'skom a bulharskom jazykovom prostredí. Slavica Slovaca, 52(1), 3-15.

Kozak, A. (2012, June 21). Dorota Sumińska - weterynarka z miłości do zwierząt. Wysokie Obcasy. Retrieved September 21, 2018, from http://www. wysokieobcasy.pl/wysokie-obcasy/1, 96856, 11917522, Dorota_Suminska_-_weterynarka_z_milosci_do_zwierzat.html?disableRedirects=true

Krongauz, M. (2018). "Avtorka", "nian'” i drugie feminitivy. Retrieved September 21, 2018, from https: //chrdk.ru/other/feminitivy

Łaziński, M. (2006). O panach i paniach: Polskie rzeczowniki tytularne $i$ ich asymetria rodzajowo-ptciowa. Warszawa: PWN.

Malinowski, M. (2006). Psycholożka, socjolożka, reżyserka [Blog post]. Retrieved September 21, 2018, from https://obcyjezykpolski.pl/psycholozka-socjolozka-rezyserka/

Małocha-Krupa, A. (2015). Słownik nazw żeńskich polszczyzny. Wrocław: Wydawnictwo Uniwersytetu Wrocławskiego.

Miodek, J. (2010). Socjolożka czy (pani) socjolog? Retrieved September 21, 2018, from http://www.gaze tawroclawska.pl/artykul/311691, jan-miodek-socjolozka-czy-pani-socjolog, id, t.html

Murdarov, V. (2011). Tazi prodavach dnes obsluzhi edna advokat i edna ministŭr. * Razvitie na ezika ili osakatiavane na ezika. Retrieved September 21, 2018, from http://www.legalworld.bg/25351.tazi -prodavach-dnes-obsluji-edna-advokati-edna-ministyr-*.html

Murdarov, V. (2012). Gramaticheski kolebaniia pri novozaetite chuzhdi dumi. In D. Blagoeva \& S. Kolkovska (Eds.), Magiiata na dumite: Ezikovedski izsledvaniia v chest na prof. d.f.n. Liliia KrumovaTSvetkova (pp. 287-289). Sofiia: AI "Prof. Marin Drinov".

Mycawka, M. (2001). Produktywne formanty słowotwórcze we współczesnej polszczyźnie (wybrane zagadnienia). In K. Machalewski (Ed.), Wspótczesna leksyka (Pt. 2). Łódź: Wydawnictwo Uniwersytetu Łódzkiego.

Pernishka, E., Blagoeva, D., \& Kolkovska, S. (2003). Rechnik na novite dumi i znacheniia v bŭlgarskiia ezik. Sofiia: Nauka i izkustvo.

Pernishka, E., Blagoeva, D., \& Kolkovska, S. (2010). Rechnik na novite dumi v bŭlgarskiia ezik (ot kraia na $X X$ i piervoto desetiletie na $X X I$ v.). Sofiia: Nauka i izkustvo. 
Sarata, N. (n.d.). Androcentryzm. Retrieved September 21, 2018, from https://rownosc.info/diction ary/androcentryzm/

Satoła-Staśkowiak, J. (2015). Najmłodsza leksyka polska i bułgarska. Warszawa: IS PAN.

Satoła-Staśkowiak, J. (2018). O imionach i współczesnych nazwach zawodów w perspektywie płci poglądowy szkic konfrontatywny. Językoznawstwo, 2018(12), 61-72. https://doi.org/10.25312/ 2391-5137.12/2018_61-72

Shemchuk, I. A., \& Andreeva, A. V. (2013). Feminizatsiia leksicheskikh izmeneniu kak problema gendernou lingvistiki. Vestnik Baltiuskogo federal'nogo universiteta im. I. Kanta, 2013(2), 86-92.

Sokolová, M. (1998). Jazyk ako zrkadlo sociálneho postavenia ženy a muža (na príklade slovenčiny). In Sociálna práca - l’udské práva - vzdelávanie dospelých: Zborník referátov z vedeckej konferencie s medzinárodnou účastou (pp. 436-447). Prešov: Filozofická fakulta Prešovskej univerzity v Prešove.

Sokolová, M. (2007). Nový deklinačný systém slovenských substantív. Prešov: Filozofická fakulta Prešovskej univerzity v Prešove.

Sosnowski, W. (2016). Forms of address as discrete modal operators. Cognitive Studies / Etudes cognitives, 2016(16), 23-32. https://doi.org/10.11649/cs.2016.003

Stoianov, S. (1980). Gramatika na bülgarskiia knizhoven ezik: Fonetika i morfologiia. Sofiia: Izd. "Nauka i izkustvo".

Sumrova, V. (2001-2002). Problemŭt za maskulinizatsiia na sŭshtestvitelnite imena. Bŭlgarski ezik, 2001-2002(1), 120-125.

Sumrova, V. (2018). Novite feminalni nazvaniia v bŭlgarskiia ezik. Sofiia: Izdatelstvo na BAN "Prof. Marin Drinov".

Tabakova, V. (1995). Zhenite v mediite i demistifikatsiiata na "triedinniia rolevi model". In Zhurnalistikata $v$ totalitarnoto $i$ posttotalitarnoto obshtestvo (pp. 80-94). Sofiia: Izdatelstvo UI "Sv. Kliment Okhridski".

Vasil'eva, A. S. (2016). Naimenovaniia lits zhenskogo pola v russkom iazyke kontsa XX - nachala XXI vekov: Semantika, struktura, funktsionirovanie (Unpublished summary of doctoral dissertation ). Moskovskiı pedagogicheskiı̌ gosudarstvennyı̌ universitet, Moskva.

Vlakhova, R. (2001). Za niakoi osobenosti na khonorikativnata sistema v SBKE. In V. Radeva (Ed.), Bülgarskiiat ezik prez XX v. (pp. 262-265). Sofiia: AI "Prof. Marin Drinov".

Zhukova, I. N., Lebed'ko, M. G., Proshina, Z. G., \& Iuzefovich, N. G. (2013). Slovar' terminov mezhkul'turnoй kommunikatsii (M. G. Lebed'ko \& Z. G. Proshina, Eds.). Moskva: Flinta.

Zidarova, V. (2014). Slovoobrazuvatelni pokhvati pri okazionalizmite v sŭvremennata bŭlgarska presa. In L. Perchekliı̆ski (Ed.), Slavistikata i bŭlgaristikata dnes: Vŭprosi, idei, posoki (pp. 602-609). Blagoevgrad: UI "Neofit Rilski".

Znepolski, I. (1997). Novata presa i prekhodŭt: Trudnoto prestrukturirane na chetvŭrtata vlast. Sofiia: Druzhestvo Grazhdanin.

This work was financed by the Polish Ministry of Science and Higher Education.

The authors declare that they have no competing interests.

Both of the authors participated equally in preparing conception and academic editing of this issue.

This is an Open Access article distributed under the terms of the Creative Commons Attribution 3.0 PL License (http://creativecommons.org/licenses/by/3.0/pl/), which permits redistribution, commercial and non-commercial, provided that the article is properly cited.

(C) The Authors 2019

Publisher: Institute of Slavic Studies, Polish Academy of Sciences 